\title{
The mediatization of ethical consumption
}

\section{Mikkel Eskjær}

MedieKultur 2013, 54, 26-46

Published by SMID | Society of Media researchers In Denmark | www.smid.dk The online version of this text can be found open access at www.mediekultur.dk

Over the years, mediatization studies have investigated the influence of media in numerous sections of contemporary society. One area that has received limited attention is the mediatization of consumption, particularly issues concerning ethical consumption. This article presents a study of how mediatization is transforming modern consumption and contributing to the mainstreaming of ethical consumption. Based on a study of a Danish online eco-store, the article argues that modern ethical consumption increasingly depends on new media practices to present sustainable consumption as practical and fashionable while effacing underlying processes of rationalisation and commercialisation.

\section{Introduction}

Broadly speaking, mediatization theory addresses the presence of media in almost all aspects of life in late modernity. It deals with classic media sociological questions regarding the interaction of media and other social systems. As such, mediatization concerns both a contemporary phenomenon and long-term developments, a distinction that also characterises recent theoretical discussions of mediatization.

The notion of mediatization has been particularly prominent in the study of political communication. Precursors can be traced back to Lippmann and different generations of 
critical theory (Adorno, Habermas). Even today, the interaction of media and politics constitutes the area of mediatization par excellence (Mazzoleni \& Schulz, 1999; Strömbäck \& Dimitrova, 2011, p. 23). Other areas for studying mediatization include the effect of media on religion, sport, family, science, and social conflicts (Altheide \& Snow, 1979; Cottle, 2006; Hjarvard \& Löwheim, 2012)

This study concerns the interaction of media and the economic system. The aim is to investigate how (new) media relates to new means of consumption. The notion of mediatization thus provides the theoretical backdrop for analysing recent developments in the area of consumption, especially ethical consumption. The argument advanced in this study is that mediatization offers new possibilities for ethically informed ways of consuming to such a degree that modern ethical consumption is not only reliant on but also, to a certain extent, a product of mediatization.

To illustrate this line of thought, the paper discusses the opportunities and constraints of mediatised ethical consumption using a case study of a Danish company. The company, called Aarstiderne (meaning 'The Seasons'), has refined a business model based on online subscriptions to organic fruit and vegetable distribution in Denmark and southern Sweden. The company's successful combination of ecology and ICT has made it a household name in Denmark and has contributed to reshaping the public image of sustainable consumption as compatible with a modern, individualised lifestyle.

While the case itself is rather limited in geographical scope, the overall intention is to combine a theoretically and empirically informed investigation of mediatization as (a) a transformative process on a general level of consumption and (b) a particular mainstreaming force on the more specific level of ethical consumption.

\section{Mediatization and ethical consumption}

The concept of mediatization gradually emerged in the 1990s and was originally related to developments in political communication, which have increasingly adapted to media formats and media strategies (Asp \& Esaiasson, 1996). The concept has been subsequently employed to describe parallel developments in other social areas where aspects of social change can be attributed to media technologies and increasing media presence (Hjarvard, 2008a, 2008b).

The concept of mediatization shares a number of theoretical and analytical affinities with the term 'media logic' (Altheide \& Snow, 1979). Media logic refers to how formats and routines of the mass media condition particular areas of public communication. The concept thus seeks to capture the influence of media logic outside of the media system: "In contemporary society, every major institution has become part of media culture: Changes have occurred in every major institution that are a result of the adoption of media logic in presenting and interpreting activity in those institutions" (Altheide \& Snow, 1979, p. 11). The analytical examples provided by Altheide and Snow include transformations of poli- 
tics, religion, and sport brought about by systemic adjustments to the power and logic of media.

Although the idea of media logic has remained an important point of reference in recent mediatization studies (Hjarvard, 2008b), the concept of mediatization still lacks clear definitions and demarcations (Livingstone, 2009). One issue involves the difference between mediation and mediatization. Another relates to the temporal scope and analytical aim of mediatization.

Concerning the former, mediation and mediatization are sometimes conflated. However, as Strömbäck points out, mediation is a more static concept referring to the technological mediation of communicative messages or communicative actions. Mediatization, on the other hand, refers to a dynamic process concerning the temporal and qualitative changes that occur in mediated communication (Strömbäck, 2008). According to Strömbäck, mediation is a necessary (though insufficient on its own) precondition for mediatization. Mediatization thus refers to the social consequences of increasing mediation, that is, the historical moment when a functionally significant amount of information and interaction in a given social system (or society as a whole) rely on mediated communication.

Concerning the temporal dimension, mediatization studies are divided into definitions of mediatization as a long-term process dating back to early manifestations of media technologies and as a contemporary phenomenon related to the role, function, and consequences of media in late modernity.

The former looks at mediatization as a historical process, defining mediatization as a meta-process on par with globalisation, individualisation, and commercialisation (Krotz, 2007). A similar perspective locates mediatization within particular media matrixes, conceived of as historical configurations of media technologies (Finnemann, 2011). Conceptualised in this manner, mediatization either resembles Thompson's notion of the "mediazation of culture" (Thompson, 1995) or has obvious affinities with the historical intentions of Medium Theory (Meyrowitz, 1994).

The other branch of mediatization studies concerns the contemporary effect of media on social organisation and institutions. The aim is to describe how media in late modernity has become a transformative agent and social force in and of itself. Hjarvard, for instance, defines mediatization as "the process whereby society to an increasing degree is submitted to, or becomes dependent on, the media and their logic [...] As a consequence, social interaction [...] take place via the media" (Hjarvard, 2008b, p. 113). In a similar fashion, Schulz views mediatization as processes of "social change in which the media play a key role" (Schulz, 2004, p. 88).

These versions of mediatization are sceptical of overly broad definitions of mediatization as a historical process. Schulz claims that concepts like mediatization, globalisation, and individualisation have "a critical and expressive function" but possess only "limited value unless it is possible to clarify their meaning and to specify their analytical usability" (Schulz, 2004, pp. 87-88). For this reason, Schulz suggests that mediatization can be operationalised 
as processes of extension, substitution, amalgamation, and accommodation, which have become instrumental in transforming contemporary societies. Likewise, Hjarvard argues that the concept of mediatization must "prove its usefulness as an analytical tool and its empirical validity through concrete studies of mediatization in selected areas" (Hjarvard, 2008b, p. 113).

One way of summing up these theoretical discussions is to regard mediatization as a media-specific contribution to the ongoing modernisation of society. The presence of media in most sectors of contemporary society has, as Schulz suggests, been key to processes of social change. These changes concern social interaction within and between social systems as well as in society at large (Hjarvard, 2008b, p. 120). In other words, mediatization entails media-induced types of social, systemic, and political integration (Mortensen, 2004).

Not all social areas have received equal attention from mediatization studies. The field of consumption has been partly neglected although studies in media advertising and branding represent a somewhat related area (Arvidsson, 2006). Classic studies of media in relation to modernity (Kracauer, 1995) and postmodernity (Baudrillard, 1988; Debord, 1972) have also touched on early tendencies of mediatised consumption.

Andre Jansson, however, explicitly connects the concept of mediatization with recent developments in consumer culture. Drawing on cultural studies and postmodern theory, Jansson argues that we have entered a new stage in the history of consumption characterised by "commercial intertextuality", in which consumer culture and media culture have merged (Jansson, 2002). Production has become a matter of "symbolic circulation", turning material goods into "symbolic systems" of values, narratives, and social distinctions. Under these circumstances, consumption is closely tied to media representations, which have become the realm of inducing and controlling the web of significance that surrounds material goods and services. In this sense, consumption has become mediatised, designating "a social arrangement in which media culture and consumer culture are no longer separable categories, and where media images and media influenced commodity-signs are to an increasing extent used as sources for, and expressions of, identity" (Jansson, 2002, p. 26). Jansson's focus is thus less on how media technologies foster new "means of consumption" (Ritzer, 2010) than on the cultural processes of commercialisation that follow in the wake of mediatization.

So far, mediatization studies have paid no attention to the issue of ethical consumption. Likewise, studies of ethical consumption have largely ignored the role of the media (Barnett, Cloke, Clarke, \& Malpass, 2011; Harrison, Newholm, \& Shaw, 2005; Lewis \& Potter, 2011b). Interestingly, however, the two disciplines share a number of features. They are both emerging fields with a growing body of literature, reflecting new practices in consumer culture and media consumption. But they also face similar challenges, as both concepts have been criticised for being too large to be meaningful. In today's media-saturated environment, everything seems to be mediatised (Livingstone, 2009), just as a wide range of sometimes contradictory practices (in relation to human rights, climate change, social justice, 
and sustainability) have been classified as ethical consumption (Littler, 2011, p. 28). Ethical consumption thus does not designate "a clearly defined set of practices" and is difficult to pin down as a result, referring to "a range of tendencies within contemporary consumer culture" (Lewis \& Potter, 2011a, p. 4).

Defined from an activist point of view, ethical consumption makes "global business more sustainable through consumer pressure" (Ethical_Consumer, 2012). In more technical terms, it refers to how economic exchange is transported into non-economic territories by reconfiguring "the privatized moment of spending as a communal act, thus positioning consumer choice as a site of responsibility" (Lewis \& Potter, 2011a, p. 4). While this type of consumer positioning has become "increasingly commonplace in today's marketplace" (ibid.), the theoretical debate centres on whether ethical consumption is to be understood primarily as a political phenomenon or as a privatised form of collective action (Barnett, et al., 2011).

Reflecting this division, Lewis and Potter distinguish between political consumerism and conscience (or ethical) consumption. Whereas political consumption refers to traditional forms of activism such as boycotts and consumer organisations, recent forms of ethical consumption are closely tied to a new cultural and political context defined by the "terrain of the everyday." Thus, the distinction indicates a shift from "external codes and values" to a new sort of post-politics or lifestyle politics in which the traditional locus of doing politics is moving from the polis to the oikos or household (Lewis \& Potter, 2011a, p. 5).

This shift involves a process of decommodification, a concept employed in consumption studies to designate a process in which the value of a given object is "re-framed" and thus exceeds purely economic exchange value. Decommodification reframes "the meaning and uses of material culture by translating the purely commercial value of goods into other forms of value: affection, relationships, symbolism, status, normality, etc." (Sassatelli, 2007, p. 139). Ethical consumption is a paradigmatic example of decommodification as the value of a given purchase is closely linked to its status as ethical, sustainable, recyclable, etc., endowing it with social distinction value (Bourdieu, 1986). These marks of social and cultural distinction have been particularly attractive to the middle class as a powerful means of discriminating against financially underprivileged groups (Littler, 2011, pp. 34-36), a mechanism that is undoubtedly central to understanding organic food consumption.

The distinction between polis and oikos - or between the political and the individualised - has a special bearing on the subject of mediatization. On the one hand, online home shopping has given the consumer opportunities to purchase ethically produced goods and services, turning private consumption into a site of micro-political engagement. At the same time, social networks and online technology have been instrumental in organising more traditional political platforms to rally against unethical consumption. Mediatization thus both contributes to the advancement of individualised lifestyle consumption as well as to the broader societal impact of consumer practices. 
As a result, combining theories of mediatization and ethical consumption highlights tensions within ethical consumption while also opening up new aspects of mediatization that revolve around normative issues concerning ethical behaviour and political mobilisation.

\section{Data and research design}

The present study can be divided into two parts, reflecting two different perspectives on the mediatization of ethical consumption. The first part takes a general and theoretically informed perspective, building on Schulz's (2004) operationalisation of mediatization as an analytical concept. Schulz's concepts are elaborated in dialogue with other concepts of mediatization as well as with concepts from studies of consumer culture. The aim is to investigate the opportunities and constraints of mediatization in relation to ethical consumption.

The second part presents a case study of the Danish company Aarstiderne.com, which has succeeded in creating a multi-million euro $(€)$ business by selling organic food through an online subscription system. It is a single-case study (Yin, 2009) of Aarstiderne as a rather unique case of ethical consumption based on information technology (within a Danish context). The analysis considers the self-presentation and media representations of Aarstiderne in order to investigate public images of Aarstiderne as an example of cyber-based, ethical consumption. Data consists of:

- Official website documents from Aarstiderne.com as well as a research interview with the company's Director of Communication ( $M$. Andersen, personal communication, April 23, 2012).

- A sample of media reports referring to Aarstiderne.com, covering a time span from 01.01.1999 to mid-April 2012. The sample frame consists of all national daily papers, and data has been obtained by searching the Danish database Infomedia for the words 'Aarstiderne' and 'organic' as well as for the names of the two founders of the company.

Methodologically, the study combines quantitative and qualitative approaches. The former takes the form of a content analysis (Krippendorff, 2004) of articles on Aarstiderne, based on a stratified sample $(n=71)$ encompassing Aarstiderne.com's first two years (1999-2001) and two most recent years (2000-2012). The analysis looks at how press reports address issues of organic consumption and to what extent they have changed over time in terms of intensity, editorial priority, and journalistic focus. Articles have been coded for length, attribution, news genre, news topics, and more specific journalistic focus on Aarstiderne.

A qualitative approach guides the interview with the director of communication as well as the analysis of website documents. It focuses on the self-understanding and self-presen- 
tation of the company in words, text, and images, including how the company has tackled the communicative potentials and constraints of different media platforms (e.g. website or news reports). In addition, the sample of press reports has been subject to a qualitative media analysis (Altheide, 1987, 1996). Unlike content analysis, qualitative media analysis rests on a reading rather than a quantification of content while still investigating multiple documents relative to context and patterns of messages over a period of time (Altheide, 1996, p. 10). The present analysis centres on the development of thematic differences and similarities in the representation of Aarstiderne across the two strata.

\section{Mediatised means of consumption}

Following Schulz's proposition, the influence of mediatization on consumption can be operationalised as processes of extension, substitution, amalgamation, and accommodation.

The suggestion that mediatization results in a process of extension draws explicitly on McLuhan's concept of "the extension of man" (McLuhan, 1967; Schulz, 2004, p. 88). Media has the capacity to overcome spatial and temporal limitations to human communication, allowing communication to take place across physical and temporal distances.

In terms of consumption, the media offers new means of purchasing goods and services, which are no longer limited to a specific geographical location or to designated hours of the day. This is what Ritzer calls the "implosion of means of consumption" (Ritzer, 2010). According to the ideal structure of the bourgeois society, purchasing goods and services was until recently located in the social sphere and separated from the sphere of intimacy (Habermas, 1971 [1962], p. 27). The invasion of media technologies into the household has, however, fundamentally changed this structure. "The home was, in the main, separate from settings in which one purchased goods and services. That barrier, however, has imploded: The home has become a, perhaps the, major site for obtaining goods and services" (Ritzer, 2010, p. 131). Early examples of domestic mediatised consumption include mail-order catalogues and telemarketing. However, the true extension of consumption brought about by mediatization lies in the possibilities presented by Internet shopping, which allows the consumer to shop anytime, anywhere.

According to Ritzer, the implosion of time and space represents the most recent example of the re-enchantment of consumption: "Borders between the means of consumption and other aspects of the social world (e.g. the family and the home) have [...] been breached [...] The result has been a reenchanted world of consumption seemingly without borders or limits" (Ritzer, 2010, pp. 118-119). Eliminating any physical or temporal restrictions to consume, the Internet is the ultimate 'cathedral of consumption', functioning in real-time, $24 / 7$, and encompassing the entire globe.

It is worth remembering, however, that the traditional locations of consumption associated with modernity, such as the supermarket and the department store, were themselves early examples of the implosion of space. According to Giddens, one of the traits of modernity 
is that space has become phantasmagoric as it is no longer organised by local structures. Giddens refers to the local grocer's shop, which is no longer an outlet for locally produced goods as was the original village market but instead offers products from all over the world (Giddens, 1994). Today, Internet consumption in online malls is a sort of second order phantasmagoric space. Not only can we buy products from all around the world in webshops all over the world, but the webshop itself is phantasmagoric, a virtual site based on digital algorithms.

The most radical consequence of mediatization is the process of substitution in which media activities substitute social activities (e.g. cinema replacing theatres, televangelism substituting churchgoing). While large-scale substitutions, in which the media replace entire social institutions, are rare and unlikely, small-scale substitutions are already taking place. The purchasing of financial goods and services is increasingly substituted by e-banking. Likewise, plane tickets and package holidays are bought online, substituting a visit to a travel agency, etc. Along with the expansion of shopping malls, e-commerce has begun to change the face of the traditional (European) city. Describing the decay on the British high streets, The Economist notes how "The steady march of out-of-town developments [...] and, more recently, of internet shopping means the proportion of retail spending captured by town centres has fallen from $49.4 \%$ to $42.5 \%$ since 2000 " (Economist, 2012).

Amalgamation and accommodation represent two other processes of mediatization, which tend to integrate media technology into other social structures in a rather organic fashion. Amalgamation refers to how media are incorporated in daily activities. Media ethnography has long pointed out how media use tends to structure everyday life, influence interpersonal relations, and reproduce social patterns (Lull, 1990; Morley, 1995). In terms of consumption, extensive media use also entails a great deal of exposure to advertising (both explicit and hidden, such as product placement, infotainment, etc.), underlining how the so-called 'consumer society' rests on media-induced needs and desires. This is what Jansson suggests in his analysis of the mediatization of consumption:

\footnotetext{
It is impossible to find any functional limits to 'consumption' or 'mediation' [...] Media culture and consumer culture are theoretically overlapping and empirically inseparable categories. [...] The scope of media culture is expanding, simultaneously changing the face of consumer culture. Mediated texts mean a great deal for the way people experience the relationship between self and the surrounding world, including the world of goods [...] As economic and cultural processes collapse into one another, the distinction between consumption and mediation vanishes as well (Jansson, 2002, pp. 11-12).
}

In recent years, consumption has thus become increasingly blended with media products, especially media-based entertainment. Visiting a fast food restaurant is also an experience of the latest Hollywood Blockbuster universe, illustrating a more general trend toward enchanting consumption by fusing shopping with fun (Ritzer, 2010). It also works the other way around: Media products have increasingly become vehicles for consumption, as illustrated by the merchandising surrounding the culture industry. 
Accommodation is perhaps the most obvious and well-documented process of mediatization. As the media industry has gained importance in economic and cultural terms as well as structured and filled people's everyday lives, other social systems have increasingly been adapting to the norms and routines of the media industry. Altheide and Snow consider this a general adaption to the logic of the media, pointing out how media formats become "a framework or a perspective that is used to present as well as interpret phenomena" (Altheide \& Snow, 1979, p. 10).

The process of accommodation illustrates how mediatization is a two-way (media ecological) process. It alters the social systems that interact with the media as well as the media system itself. Accommodation is thus also a process through which the media has benefitted enormously. As politicians have adjusted to the power and importance of the media system, resulting in what Castells calls 'communication power' (Castells, 2009), the media system has become a pillar of modern democracies (Hallin \& Mancini, 2004). However, the mutual benefit of mediatization is probably best exemplified by the role and function of advertising in developing and sustaining the media system. Recent developments in the newspaper market illustrate the extent to which the media are profiting from and dependent on advertising revenues.

\section{Mediatised consumption: new settings for ecological consumption}

Mediatization offers new possibilities for ethical consumption. It may alter, sidestep, or even create new forms of supply as well as support or generate new forms of demand. But it also carries certain restrictions, limitations, and perhaps even unintended consequences. Thus, in all of the four processes of mediatization proposed by Schulz, we can identify potential opportunities and obstacles in relation to ethical consumption.

Mediatization, especially the prospects for online shopping, offers an unprecedented opportunity to extend consumption both in terms of what and where to purchase. From an ecological perspective, this prompts hope and despair. On the one hand, extension allows the consumer to redirect consumption by gaining access to sustainable products and bypassing traditional means of consumption. Ideally, cyber markets and online shopping (from home, from work, or during commutes) could reduce transportation to and from supermarkets and shopping centres, which has been calculated to reduce energy consumption (Danmarks_Aktive_Forbrugere \& Juul, 2003). Globalised communication on the Internet has also helped inform and mobilise ethical consumers through alternative consumption websites, ethical shopping guides, and moral boycotts, aiming to challenge corporate power and democratise the market (Ethical_Consumer, 2012). As Mike Featherstone notes, "Information technologies which sustain global financial markets and transnational corporate production also make possible greater flows of information between consumer-citizens" (Featherstone, 2011, p. xviii). 
On the other hand, the extension of ethical consumption risks stimulating more consumption and transportation as it facilitates purchases of ethical products from all over the world. As Monbiot (2007) wryly observes, "It is easy to picture a situation in which the whole world religiously buys green products, and its carbon emissions continue to soar." In this sense, mediatization underlines how easily ethical consumption turns into "contradictory consumption" (Littler, 2011, p. 28).

Ultimately, the extension of consumption might result in a process of substitution in which mediatised consumption replaces traditional consumption. E-commerce may hold the potential for less transportation, a bigger market for sustainable products, more efficient lines of distribution, etc. However, the process of rationalising sustainable consumption comes with a price. It necessarily leads to centralisation and the risks of eliminating local markets. A paradoxical consequence of mediatization may be the purchasing of organic food on the Internet instead of buying local products. As such, mediatization may support the economy of ecological production but not necessarily the ideology of ecological consumption.

Of the four processes of mediatization suggested by Schulz, the concept of amalgamation is perhaps the most difficult to apply to ethical consumption. After all, ethical consumption is a rather conscious act often directed at purchasing niche products, which may be difficult to integrate into media activities. A gradual integration of media-informed consumer habits also carries the risk of commercialising sustainable consumption, thereby becoming yet another means of re-enchanting consumption. To some extent, this has already happened. As Dryzeck points out, 'sustainability' is a rather weak term (Dryzek, 2005). Consequently, major commercial players have been able to embrace the political discourse of sustainability, using the media to cultivate images of green enterprises, green brands, and the somewhat oxymoronic term green consumption.

This illustrates the last of the four process of mediatization, namely accommodation. Since, as Jansson points out, the media "mean a great deal for the way people experience the relationship between self and the surrounding world, including the world of goods," producers of goods and services have adjusted their products and images to the public discourse of sustainable consumption. This has increasingly led to greenwashing (Terrachoise, 2009), eco-junk (Monbiot, 2007), and a proliferation of all sorts of eco-labelling (national, transnational, commercial), which may confuse rather than inform consumers.

The upshot is that, in today's media-permeated society, no one, including large multinational companies, can ignore media discourses and the mediatization of consumption. This situation may force companies to adapt to ethical consumption, as the development of corporate social responsibility has indicated (Adams \& Zutchi, 2005). The media plays a significant role in this process. This is in part because new media technologies disseminate information instantly (regardless of its degree of accuracy), including calls for ethical boycotts (or 'buycotts'), but also because the mediatization of consumption has given the consumer new tools to seek alternative goods and services. 


\section{Aarstiderne.com: ecology in cyberspace}

Aarstiderne is a Danish company that mainly distributes organic fruit and vegetables to approximately 40,000 households in Denmark (reaching about 1.6 pct. of all Danish households). It also operates in southern Sweden (5000 customers) and, for a short time, tried to establish a market in Germany. The business model is based on distributing (recycled) boxes containing organic fruit and/or vegetables. The boxes are delivered directly to the consumer on a weekly or bi-weekly basis.

Aarstiderne.com has succeeded in combining idealism and commerce, illustrating a central tenet of (early) Internet culture (Castells, 2003). As the manager indicates, "We've founded the company because we want to live properly and sustainably [...] We want to give people a better daily diet based on the principle 'from soil to stove', and we want to introduce some ethics in relation to foodstuffs" (Jyllandsposten 30.07.2011). Despite, or perhaps because of, these principles the company has grown to today's level of 150 employees and an annual turnover of $€ 35$ million.

Although a relatively small Scandinavian company, Aarstiderne has been called "a sustainable empire" and "the world's largest box scheme" by Time Magazine (Abend, 2009). Within a Danish context, the description is not entirely hyperbolic. While serving only a minor part of the market for organic products (approximately 7.6 pct.), Aarstiderne dwarfs all other similar "box schemes" in Denmark. The company's success has made it a "lighthouse" in Danish ecology (Jyllandsposten 02.09.2010, p. 5), earning it a position as a symbol and point of reference in public discourses on sustainability.

The following sections look at Aarstiderne.com as an example of mediatised ethical consumption, both in terms of how the company utilises information technologies to sell and promote organic groceries and in terms of media representations of Aarstiderne.com. While media exposure functions as a sort of free advertising, it is also part of a wider 'mediatization' of ecology, illustrating how media representations are instrumental in drawing public attention to alternative lifestyles, ethical consumption, and sustainable development.

\section{Ethical cyber market}

Aarstiderne.com emerged out of two separate companies that produced organic vegetables for local customers. Both companies were based on customers picking up boxes from the producer, and both experienced similar setbacks: Customers forgot to collect their boxes, went on holiday, etc.

In order to tackle these problems, the two companies merged as Aarstiderne in 1999 and began distributing boxes directly to customers, who could now subscribe for boxes on a weekly or bi-weekly basis. Later in 1999, Aarstiderne went online, becoming - according to the company - a Danish pioneer in exploring the potentials of the Internet (Aarstiderne, 2012). 
The decision to go online coincided with the spread of Internet technology in Danish households, as illustrated in Figure 1. It enabled a new business model in which the subscriber could order, cancel, or postpone deliveries or add new products to his or her next delivery. According to the company itself, the commercial take-off was closely associated with its online activities ( $M$. Andersen, personal communication, April 23, 2012). After just two years of existence, the number of subscribers had increased eightfold, from around 1,000 subscribers to 8,000+ (Politiken 28.10.2000).

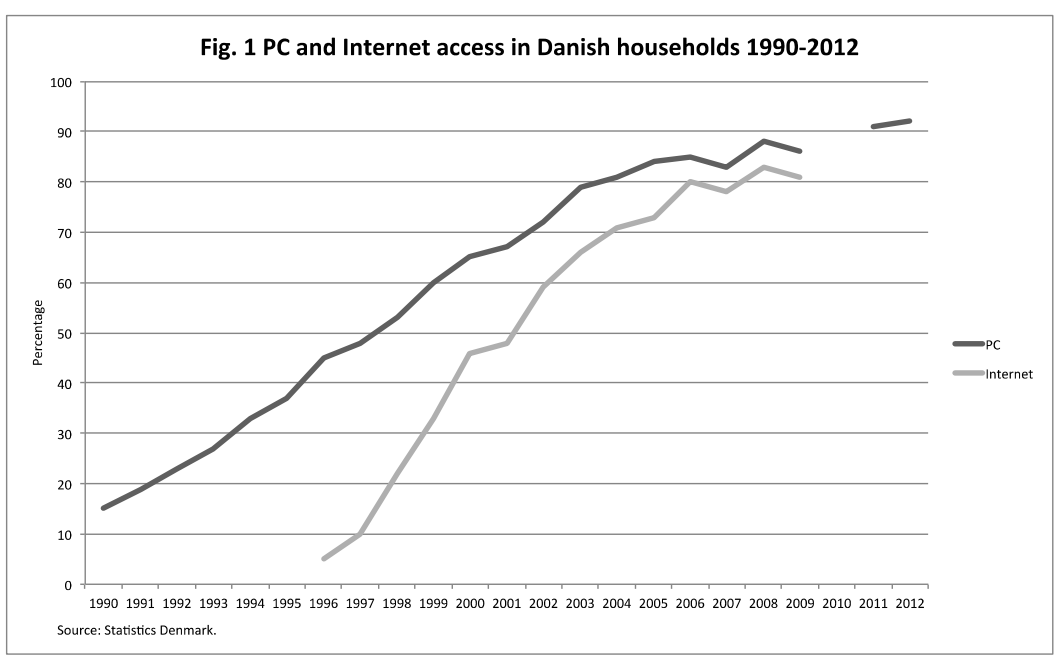

The success of Aarstiderne is thus to a certain degree a story of two different structural conditions. First, along with Switzerland, Denmark has the highest consumption of organic goods measured in terms of per capita spending (Bio-Fach, 2011). Second, according to ITU, Denmark is ranked within the top four in the 2008 and 2010 ICT development indexes (ITU, 2011, p. 13).

However, the relative success of Aarstiderne.com also illustrates aspects of mediatization theory. First and foremost, using the Internet as the main means of contact with customers is a clear example of the process of extension provided by new media. Online technology allows the customer to purchase organic food from one place (most likely home) instead of seeking out organic products at specialised shops and supermarkets. "Visiting www.aarstiderne.com is like walking into an organic supermarket on your desktop," reports an early news story (Jyllandsposten 11.10.2001).

Recently, customers have even called for an application for mobile phones in order to shop "while on the move," as expressed by a customer. This is something the company plans to pursue in the near future.

Online eco-shopping broadens the range of products, allowing the customer to partially personalise ethical consumption. Thus, besides subscribing to an organic fruit and/ or vegetable box, customers can order organic meat, poultry, wine, beer, bread, cheese, etc. Boxes are furthermore differentiated between ordinary organic boxes and a "dogma 
box" consisting only of Danish-produced organic vegetables, arguably the most sustainable product. It is also possible to purchase a so-called "Africa bag" developed in collaboration with development organisations like CARE and Danish Refugee Council and consisting of fair trade fruits and spices from Uganda.

One of the intentions behind Aarstiderne.com was to minimise the distance from "soil to stove," which is the company's central motto. Aarstiderne produces a great deal of its fruits and vegetables at three farms located in different places in Denmark and also imports organic products. Using online technology and direct delivery is therefore a means of bypassing or substituting traditional retailers, something that the 'box scheme' aimed for from the very start. Aarstiderne thus illustrates how the extension of consumption by means of media technology not only supplements but to some extent substitutes existing forms of organic purchasing and shopping in general. As one of the founders of Aarstiderne puts it, "Lots of people want quality and organic. Especially if they can avoid the shopping basket and instead spend the time in the kitchen" (Politiken 28.10.2000, p. 4).

The process of amalgamation is much harder to measure. It concerns the extent to which ethical consumption has become integrated into other social activities and to which this can be attributed to the effects of mediatization. Investigating such a connection goes beyond the scope of the present study and would probably involve more detailed consumer studies. However, as will be discussed in the next section, there seems to be a correlation between media attention to organic products and an increase in organic consumption, although the direction of this correlation is difficult to determine. This is, admittedly, a weaker sort of integration than that suggested by the concept of amalgamation, but it nevertheless points to a relationship between media representations and consumer habits.

The process of accommodating sustainable consumption to the possibilities and challenges of mediatization takes place at several levels. While embracing modern media technology, Aarstiderne is well aware of the constraints of mediatised eco-shopping. Substituting face-to-face communication with online communication is the means of connecting "soil and stove," but this involves certain limitations as well. According to Aarstiderne's own research, customers recruited via the Internet are less loyal compared with customers who have been introduced to Aarstiderne by a sales representative $(M$. Andersen, personal communication, April 23, 2012). The company therefore invites all new customers on a tour of the company's farms and often organises events (markets, lectures, pop-up restaurants, etc.) in order to establish personal contact with new or potential customers.

Another challenge for online shopping is endowing the experience with some sort of value added. The manager says:

The customers should get more than just the produce. They should obtain something they would not get otherwise. Something that doesn't exist in their physical world. And we offer that by adding recipes. By offering people the opportunity for living healthily with a better conscience. [...] It's all about the good story that people receive as part of the purchase. (Jyllandsposten 17.05.2001, p. 7) 
As a result, Aarstiderne has combined media and non-media activities from the very beginning. The initial growth of the company rested almost entirely on word-of-mouth endorsements, and to date, the budget for traditional advertising has been extremely small and mostly limited to online advertisements (banners) and indirect PR through press contacts. However, to actually place an order, the customer needs an Internet connection or, alternatively, to make a phone call.

By trying to strike a balance between organic online shopping and traditional commerce, Aarstiderne provides an example of the opportunities and challenges involved in the mediatization of sustainable consumption. At the same time, Aarstiderne is part of a wider mediatization of ecology and ethical consumption taking place in the realm of public communication.

\section{Ecology, consumption, and mass media}

Various data documents that sustainable consumption in Denmark has taken root both privately and publicly. In terms of private consumption, the share of organic products in overall food consumption is 7.6 pct. (Politiken 12.04.2011). At the same time, ecology has entered public and political discourse, as illustrated in Figure 2, which compares the use of the word 'ecology' with that of other traditional news topics over the past two decades. Although this represents a rather crude measure, the figure shows that ecology has become an integral part of the national news agenda and relatively unaffected by so-called 'issue attention cycles' sometimes associated with environmental news (Downs, 1972; Hansen, 2010).

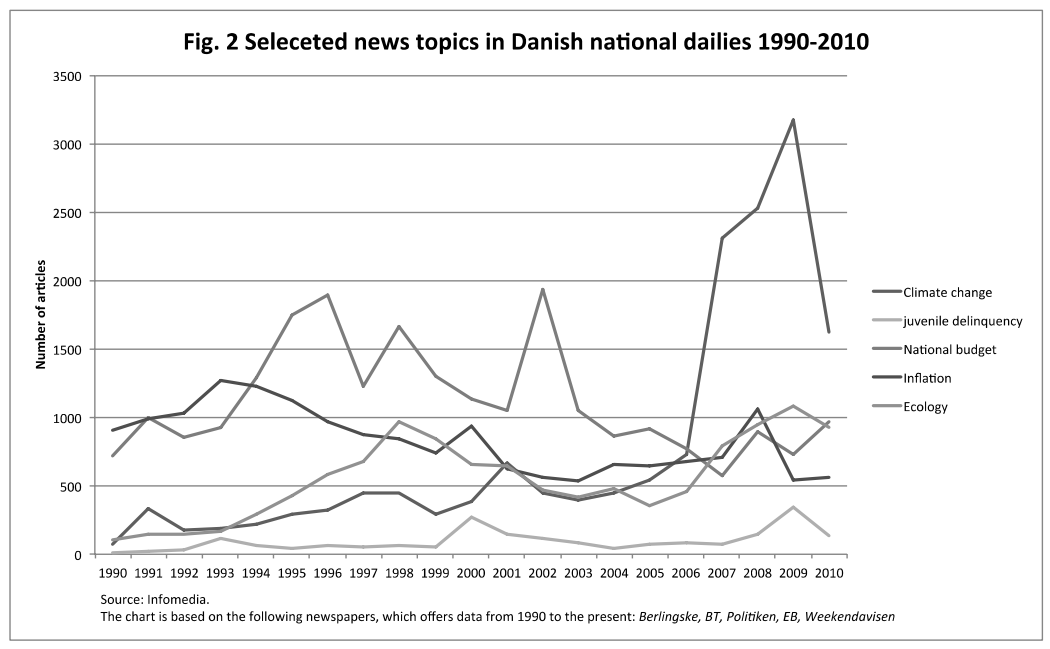

As part of this general interest in ecology, Aarstiderne.com has succeeded in attracting a high degree of public attention. There are several reasons for this, including that Aarstiderne represents a new concept of consumption ("newness"), was among the first Danish 
online shops ("relevance"), experienced exceptional growth ("success"), has organised a number of attention-grabbing events ("surprise"), and, unlike many other online firms, survived the dot.com crisis in the early 2000s ("exception"). Database figures thus show that Aarstiderne (or its founders) have appeared repeatedly in the media and across various media platforms since the company was formed in 1999 (see Figure 3). On average, Aarstiderne has been mentioned in various media 10.4 times per month since the company's founding and roughly twice per month (1.93) in the national dailies.

According to Aarstiderne, the numbers in Figure 3 are very conservative. They do not include media appearances that only indirectly concern Aarstiderne. For instance, in the start-up phase, the young and outspoken manager often featured as a star chef in various talk shows. However, this sort of PR is rarely registered and is thus difficult to detect using online databases.

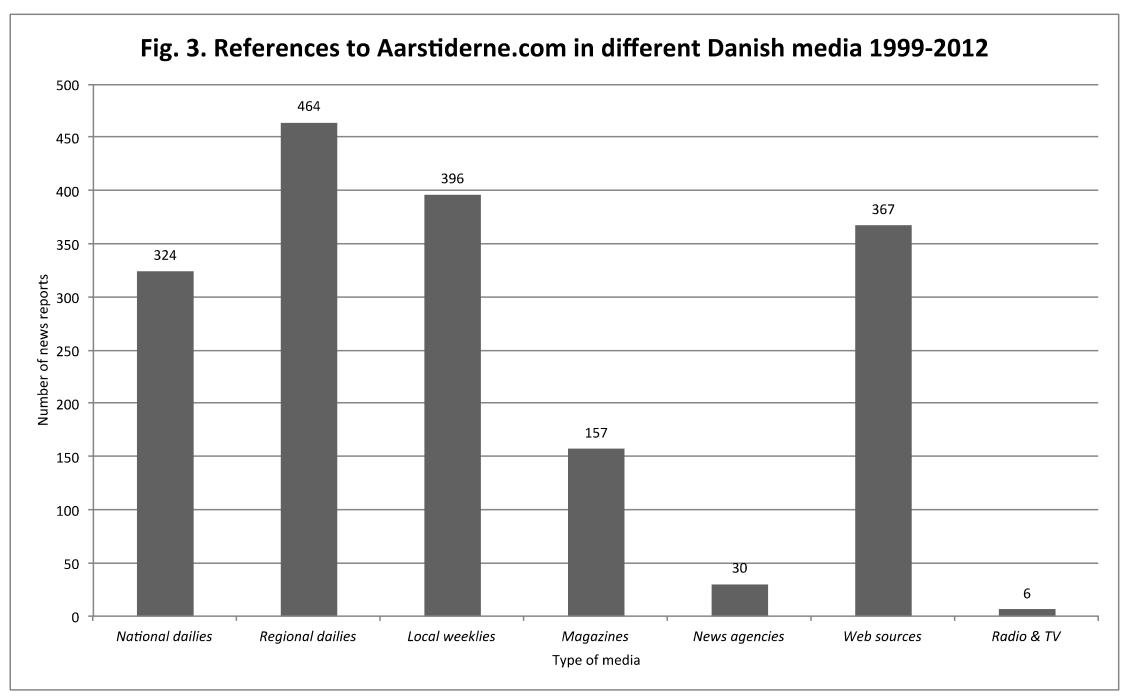

The following figures are restricted to press reports in national dailies in order to get a sense of how Aarstiderne is presented to the general public. Generally speaking, Aarstiderne receives fairly equal press coverage across different types of newspapers. Based on a stratified sample ( $n=71)$ of early (1999-2000) and recent press reports (2010-2012), the typical news story on Aarstiderne is a bylined article ( $82 \mathrm{pct}$.) dealing with aspects of the economy and/or consumption (36 pct.). Furthermore, Aarstiderne is never front page news and is rarely mentioned in editorials ( 3 pct.) or op-eds ( 3 pct.) but is more frequently the subject of news paragraphs (12 pct.).

In terms of news categories, Aarstiderne is mostly part of 'soft news' related to the economy, business, and consumption (36 pct.); portraits of the company and/or its personalities (13 pct.); or miscellaneous topics such as pop-up events and cook books (30 pct.). Only occasionally is Aarstiderne mentioned in relation to politics and the arts. In terms of journalistic focus, Aarstiderne is primarily associated with ecology (34 pct.), food and consumption (34 pct.), lifestyle (10 pct.), and IT and media (14 pct.). 
All in all, Aarstiderne is surrounded by the positive representations associated with two apparently different discourses, namely online shopping and ecology, which tend to fuse into a more general focus on green lifestyles and sustainable consumption.

Whether media reports on ecology or Aarstiderne result in consumers actually placing online orders at www.aarstiderne.com cannot be inferred from this study. According to Aarstiderne, general media exposure cannot be registered directly in sales figures although particular media attention to Aarstiderne (e.g. participating in a TV show) may result in a sudden dramatic sales increase ( $M$. Andersen, personal communication, April 23, 2012). It nonetheless indicates that the success of Aarstiderne takes place within a larger context of mediated discourses on ecology and sustainable consumption.

\section{Ecological web shopping: re-enchantning or mainstreaming ethical consumption?}

Aarstiderne presents itself to the public as a mix of new and old, quality and efficiency, local and trans-local, real and virtual. It is this complex gestalt of something material and immaterial to which the customer literally 'subscribes'. The fusion of these different attributes is symbolised through the spelling of its name (using the old letter Aa instead of the modern letter $\AA$ ) and through its logo (the combination of @ and Aa), thereby fusing the modern and the traditional, the low-tech and the high-tech in a single symbol (cf. Figure 4).

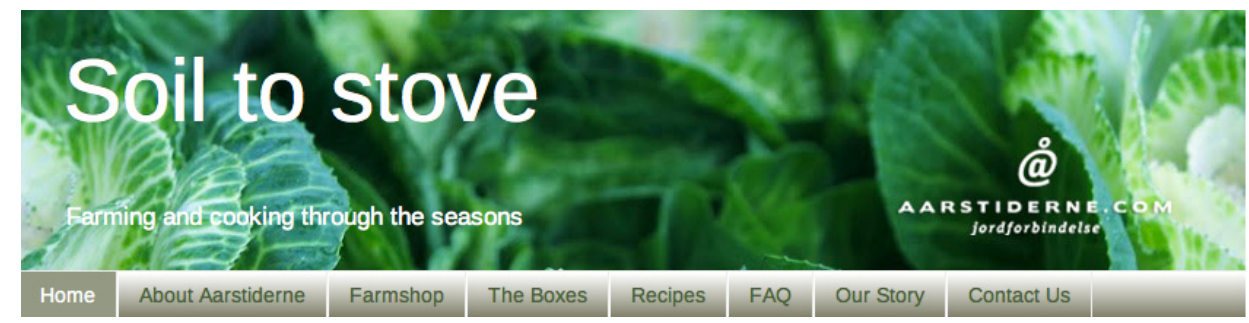

The logo of Aarstiderne (taken from English website).

Aarstiderne promises to re-establish contact with nature on several levels. By subscribing to organic boxes, customers get a sample of nature delivered to their doorsteps every week. From an economic point of view, mediatization helps support organic farming and thus the preservation of a traditional way of life. At the same time, customers engage in messages and functionalities on Aarstiderne.com, such as images of fields and barns, organic recipes, web TV, or blogs on the coming and going of agricultural seasons. At this semiotic level, customers are invited to participate symbolically in a way of life that, on the one hand, is brought to them once a week in a box yet, on the other hand, is far removed from the ordinary lives of most urban consumers.

Associating ecology with online technology and modern lifestyles helps to "demystify ecology," as the manager highlights a number of times (Jyllandsposten 11.01.2001, p. 2; 
02.09.2010, p. 5). Bringing ecology (or more precisely, sustainable consumption) online changed the image of ecology from being hippie and anti-modern to being something modern, practical, and even trendy.

Mediatization thus contributes to the re-enchantment of consumption by re-framing it as sustainable, based on principles and values that pretend to transgress - perhaps even defy - traditional consumption. As such, mediatised ethical consumption entails a number of dichotomies. Aarstiderne is selling physical products by means of virtual and immaterial technologies as well as offering narratives of sustainable production and a modern ethic of healthy living. As the manager observes, "The governing idea of taking care of the soil is extremely important. If we cannot communicate, maintain, and improve the expression of this moral attitude, we [the business] will die" (Jyllandsposten, 11.01.2001). Aarstiderne is thus promoting some of the most basic products in human nutrition as expressions of a higher purpose, whether the customer's health, respect for nature, or the preservation of traditions.

This complex relationship is sometimes described as a process of commodification and decommodification in which the consumer purchases not only a commodity but also a self-understanding and self-presentation. As such, consumers "actively participate in the process of decommodification, producing themselves as the source of value" (Sassatelli, 2007, pp. 149, emphasis in original). Media - such as company websites, PR, and mass media representations - have become important sources of securing this decommodification by endowing consumption with lifestyle values and narratives. At the same time, they serve to overshadow or at least downplay the somewhat contradictory logics in question when sustainability becomes big business.

Unsurprisingly, the majority of Aarstiderne's customers are city dwellers. According to the company, three-quarters of its customers live in the Copenhagen metropolitan area: "We are looking for the areas where people live because, if the commodities are to be transported too far out to the countryside, then most of the ecology vanishes" (Politiken 02.10.2000, p. 8). Nevertheless, the demographic distribution of Aarstiderne's customers entails its own paradoxes, at least from an ecological point of view. As Aarstiderne's central packing and distribution facility is located in West Denmark, vegetables produced in East Denmark have to be transported west for packing and then back to Copenhagen (East Denmark) for distribution: "And that is not particularly environmentally correct," the company flatly admits, before continuing, "We can't be $100 \%$ green. But we're still greener than other big providers" (Politiken 08.08.2001, p. 3).

These ecological challenges reveal how Aarstiderne.com represents a systematised ethics. In order to provide a sustainable product, it must be organised and systematised along the lines of modern transportation, production, packaging, and distribution. Like any other commercial company, Aartiderne.com has been subsumed by the imperatives of rationalisation and bureaucratisation (Ritzer, 1996; 2010).

The mediatization of sustainable consumption thus seems to rest on a paradox. One the one hand, Aarstiderne.com illustrates how mediatization is a driving force in facilitat- 
ing and mainstreaming ethical consumption. By substituting face-to-face interaction with online technology and by changing the site and settings of modern consumption, Aarstiderne.com represents the 'new means of consumption' associated with media technology and mediatization. As such, mediatization accelerates a high-tech push to an already ongoing process of modernisation in which traditional ethics (sustainable living), traditional values (respect for quality), and traditional ways of life (from soil to stove) are rationalised, systematised, and commercialised with the help of modern logistics, marketing, and information technology.

On the other hand, the mediatization of ethical consumption tends to conceal or downplay this inherent systematisation and rationalisation through a process of decommodification, which entails the dissociation of mass consumption. The promised extension and substitution offered by modern information technology make sustainable consumption less tedious, more efficient, and apparently also more ethical. They remove and isolate sustainable consumption from ordinary consumption by associating it with a seemingly immaterial universe of online purchasing and information, which magically delivers naturein-a-box every week or fortnight. At the same time, media representations construct and legitimise ethical consumption as the anti-thesis of mass consumption. They promise the consumer more time and freedom as well as support for sustainability and organic agriculture through the very act of consumption, which is otherwise associated with unsustainability and environmental degradation.

The mediatization of ethical consumption thus entails critical issues and concerns, including rarely addressed issues involving the unsustainability of media activities (Maxwell \& Miller, 2012) and the potential status of ethical consumption as a primarily middle class phenomenon of social distinction (Littler, 2011). This study, however, has mainly presented mediatization as facilitating a media-specific modernisation of ethical consumption by changing the face and function of consumption through new means and patterns of media activity. Mediatization integrates different social domains and activities on political, social, and institutional levels. It resituates political consumption by empowering the consumer through information and by expanding and rationalising the market for ethical products. As a result, political activism and consumption are combined in new ways, primarily taking place online and in private and domestic settings, thereby redefining notions of political participation. Mediatization also expands the kind and range of daily or neardaily media activities by integrating online technology and shopping, thereby diffusing the separation between private/public, home/shopping, intimacy/economy. Through this process, media consumption changes from involving the consumption of primarily symbolic goods (film, music, books, etc.) to the purchasing of services and physical goods (clothes, travels, food, etc.). Conceptualising mediatization as a process of modernisation is thus not about rendering ethical consumption more (or less) modern. Rather, mediatization represents modernisation "in a different way" (Bauman, 2000, p. 28), in which media and media 
technology reconfigure the relationships between consumption, market, and politics as well as between the forces of individualisation, rationalisation, and commercialisation.

\section{Notes}

1. For a somewhat different account of the role and function of the home in developing the modern consumer society, see Sassatelli, 2007, p. 27.

\section{References}

Abend, L. (2009). Thomas Harttung. Time Magazine, 22.09.2009.

Adams, C.A., \& Zutchi, A. (2005). Corporate Disclosure and Auditing. In B. Harrison, T. Newholm \& D. Shaw (Eds.), The Ethical Consumer (pp. 207-217). London: Sage.

Altheide, D.L. (1987). Ethnographic Content Analysis. Qualitative Sociology, 10(1), 65-77.

Altheide, D.L. (1996). Qualitative media analysis. Thousand Oaks: Sage.

Altheide, D.L., \& Snow, R.B. (1979). Media Logic. London: Sage.

Arvidsson, A. (2006). Brands, meaning and value in media culture. London: Routledge.

Asp, K., \& Esaiasson, P. (1996). The Modernization of Swedish Campaigns: Individualization, Professionalization, and Medialization. In P. Mancini \& D.L. Swanson (Eds.), Politics, Media and Modern Democracy. An International Study of Innovations in Electoral Campaigning and Their Consequences (pp. 73-90). Westport: Praeger.

Barnett, C., Cloke, P., Clarke, N., \& Malpass, A. (2011). Globalizing Responsibility. The Political Rationalities of Ethical Consumption. Chichester: Wiley-Blackwell.

Baudrillard, J. (1988). The Ecstacy of Communication. New York: Semiotext(e).

Bauman, Z. (2000). Liquid Modernity. Cambridge: Polity.

Bio-Fach. (2011). Market report: Europeans enjoy organic food worth some 18 billion EUR. Retrieved 20.08, 2012, from http://www.biofach.de/de/presse/presseinformationen/marktbericht_europa_e.

Bourdieu, P. (1986). Distinction. A social critique of the judgement of taste (R. Nice, Trans.). London: Routledge.

Castells, M. (2003). Internetgalaksen. København: Systime.

Castells, M. (2009). Communication Power. Oxford: Oxford UP.

Cottle, S. (2006). Mediatized Conflicts: Development in Media and Conflicts Studies. Berkshire: Open University Press.

Danmarks_Aktive_Forbrugere, \& Juul, J. (2003). Økologi og transport - Miljøbelastning ved transport af $ø$ kologiske fødevarer. Retrieved from http://www.pegasi.dk/transport/index.htm.

Debord, G. (1972). Skuespilsamfundet. København: Rhodos.

Downs, A. (1972). Up and Down with Ecology - the 'Issue-Attention Cycle'. The Public Interest, 28 (Summer), 38-50.

Dryzek, J.S. (2005). The Politics of the Earth. Environmental Discourses. Oxford: Oxford UP.

Economist. (2012). Nation of shop critics. Economist, The, 21.01.2012.

Ethical_Consumer. (2012). About us. Retrieved 10.05.2012, from http://www.ethicalconsumer.org/aboutus. aspx.

Featherstone, M. (2011). Foreword. In T. Lewis \& E. Potter (Eds.), Ethical Consumption. A critical introduction (pp. xvii-xxviii). Oxon: Routledge. 
Finnemann, N.O. (2011). Mediatization theory and digital media. Communications(36), 67-89.

Giddens, A. (1994). Modernitetens konsekvenser (S.S. Jørgensen, Trans.). København: Hans Reitzels Forlag.

Habermas, J. (1971 [1962]). Borgerlig Offentlighet - dens fremvekst og forfall. Henimot en teori om det borgerlige samfunn (E. Schwabe-Hansen, H. Høibraaten \& J. Øien, Trans.). Oslo: Gyldendal.

Hallin, D.C., \& Mancini, P. (2004). Comparing Media Systems. Three Models of Media and Politics. Cambridge: Cambridge UP.

Hansen, A. (2010). Environment, Media and Communication. London: Routeledge.

Harrison, R., Newholm, T., \& Shaw, D. (Eds.). (2005). The Ethical Consumer. London: Sage.

Hjarvard, S. (2008a). En verden af medier. Medialiseringen af politik, sprog, religion og leg. København: Samfundslitteratur.

Hjarvard, S. (2008b). The Mediatization of Society. A Theory of the Media as Agents of Social and Cultural Change. Nordicom Review, 29(2), 105-134.

Hjarvard, S., \& Löwheim, M. (Eds.). (2012). Mediatization and Religion. Nordic Perspectives. Göteborg: Nordicom.

ITU. (2011). Measuring the Information Society (2011 ed.). Geneva: International Telecommunication Union. Jansson, A. (2002). The Mediatization of Consumption : Towards an analytical framework of image culture. Journal of Consumer Culture, 2(5), 5-31.

Kracauer, S. (1995). The Mass Ornament. Weimar Essays. Cambridge, Mass.: Harvard UP.

Krippendorff, K. (2004). Content Analysis. An Introduction to Its Methdology (2. ed.). Thousand Oaks: Sage.

Krotz, F. (2007). The meta-process of 'mediatization' as a conceptual frame. Global Media and Communication, 3(3), 256-260.

Lewis, T., \& Potter, E. (2011a). Introducing ethical consumption. In T. Lewis \& E. Potter (Eds.), Ethical Consumption. A ciritical introduction (pp. 3-23). Oxon: Routledege.

Lewis, T., \& Potter, E. (Eds.). (2011b). Ethical Consumption. A critical introduction. Oxon: Routledge.

Littler, J. (2011). What's wrong with ethical consumption. In T. Lewis \& E. Potter (Eds.), Ethical Consumption. A critical introduction (pp. 27-39). Oxon: Routledge.

Livingstone, S. (2009). On the Mediation of Everything. Journal of Communication, 59(1), 1-18.

Lull, J. (1990). Inside Family Viewing. Etnographic Research on Television's Audiences. London: Routeledge.

Maxwell, R., \& Miller, T. (2012). Greening the Media. New York: Oxford UP.

Mazzoleni, G., \& Schulz, W. (1999). "Mediatization" of Politics: A Challenge for Democracy? Political Communication, 16, 247-261.

McLuhan, M. (1967). Mennesket og medierne. København: Gyldendal.

Meyrowitz, J. (1994). Medium Theory. In Crowley \& Mitchelle (Eds.), Communication Theory Today. Cambridge: Polity Press.

Monbiot, G. (2007, 24th July). Eco-junk, The Guardian. Retrieved from http://www.monbiot.com/2007/07/24/ eco-junk/.

Morley, D. (1995). Television and Gender. In O. Boyd-Barrett \& C. Newbold (Eds.), Approaches to Media. A Reader (pp. 518-524). London: Arnold.

Mortensen, N. (2004). Det paradoksale samfund. Undersøgelser af forholdet mellem individ og samfund. København: Hans Reitzels Forlag.

Ritzer, G. (1996). McDonaldiseringen af samfundet (S. S. Jørgensen, Trans.). København: Hans Reitzels Forlag.

Ritzer, G. (2010). Enchanting a Disenchanted World. Continuity and Change in the Cathedrals of Consumption (3rd ed.). Thousand Oaks: Pine Forge Press.

Sassatelli, R. (2007). Consumer Culture. History, Theory and Politics. London: Sage.

Schulz, W. (2004). Reconstructing Mediatization as an Analytical Concept. European Journal of Communication, 19(1), 87-101. 
Article: The mediatization of ethical consumption

Strömbäck, J. (2008). Four Phases of Mediatization: An Analysis of the Mediatization of Politics. The International Journal of Press/Politics, 13(3), 228-246.

Strömbäck, J., \& Dimitrova, D.V. (2011). Mediatization and Media Interventionism: A Comparative Analysis of Sweden and the United States. The International Journal of Press/Politics, 16(1), 30-49.

Terrachoise. (2009). The Seven Sins of Greenwashing. Environmental Claims in Consumer Market. Ottawa: Terrachoise.

Thompson, J.B. (1995). The Media and Modernity. A social theory of the media. Cambridge: Polity Press.

Yin, R.K. (2009). Case Study Research. Design and Methods (4. ed.). Thousands Oaks: Sage.

Aarstiderne. (2012). Om Aarstiderne. Retrieved 10.05.2012, from http://www.aarstiderne.com/Omaarstiderne.

\author{
Mikkel Eskjæer \\ Associate Professor, PhD \\ Department of Communication \\ Aalborg University Copenhagen, Denmark \\ eskjaer@hum.aau.dk
}

